\title{
Seagrass meadow structure alters interactions between the sea urchin Paracentrotus lividus and its predators
}

\author{
Simone Farina ${ }^{1, *}$, Fiona Tomas ${ }^{1}$, Patricia Prado ${ }^{1}{ }$, Javier Romero ${ }^{2}$, Teresa Alcoverro ${ }^{1}$ \\ ${ }^{1}$ Centre d'Estudis Avançats de Blanes (CSIC), Accés a la Cala Sant Francesc 14, 17300 Blanes, Girona, Spain \\ ${ }^{2}$ Departamento de Ecologia, Faculdad de Biologìa, Universidad de Barcelona, Avda. Diagonal 645, 08028, Barcelona, Spain
}

\begin{abstract}
Predation on sea urchins, which are important structuring agents in seagrass communities, can be modulated by habitat structural complexity. Here we examine the importance of meadow structure (leaf length and presence of unburied root-rhizome layer) in determining predation pressure on the main invertebrate herbivore of the temperate seagrass Posidonia oceanica (L.) Delile, the sea urchin Paracentrotus lividus (Lamarck). The attributes of seagrass habitat complexity are subject to considerable spatial and temporal variability, thus affecting refuge availability. In the field, exposure of the root-rhizome layer depends on local sedimentary conditions, while changes in the leaf canopy are generally dictated by hydrodynamic regimes, light, nutrient availability as well as grazing activity. We reproduced 5 habitat conditions in the laboratory and 2 in the field by modifying leaf length and burial level of the root-rhizome layer, and we measured fish predatory efficiency under controlled conditions. In the laboratory we focused on juvenile sea urchins $(0.2$ to $1.2 \mathrm{~cm}$ test diameter, TD) while in the field we studied young adults (3 to $5 \mathrm{~cm}$ TD). Mortality of juveniles and young adults was significantly lower under long leaves, while the presence of an unburied root-rhizome layer appeared to provide a key refuge for juveniles, independent of leaf length. The presence of refuges thus appears to be a key factor in the interaction between sea urchins and predatory fish in seagrass meadows, and highlights the importance of local structural complexity (e.g. sedimentary regimes, fish herbivory pressure) on the regulation of predator-prey interactions.
\end{abstract}

KEY WORDS: Posidonia oceanica $\cdot$ Paracentrotus lividus $\cdot$ Herbivores $\cdot$ Trophic cascades $\cdot$ Top-down control $\cdot$ Refuge $\cdot$ Canopy

Resale or republication not permitted without written consent of the publisher

\section{INTRODUCTION}

Predation is an important structuring agent in marine communities, and its intensity is strongly dependent on the presence of refuges, and hence spatial complexity. In seagrass meadows there are multiple elements of plant morphology or architecture that contribute to habitat structural characteristics, from the simplest (e.g. leaf surface area) to the most complex (e.g. number and size of blades, branching pattern, presence of a bare root-rhizome layer). All of these elements can provide refuge for a variety of organisms (e.g. Orth et al. 1984, Heck \& Wilson 1986). In fact, sea- grass habitat serves as refuge from predation for various prey fish and invertebrate species (Savino \& Stein 1982, Orth et al. 1984, Heck et al. 1989, Orth 1992, Harris et al. 2004). Additionally, vegetation is constantly affected by multiple biotic and abiotic processes (i.e. seasonal leaf loss, leaf loss by storms or currents, grazing), which can potentially modify habitat structure and, consequently, influence predatory interactions (Savino \& Stein 1982).

Sea urchins are known to play an important role in the control of submersed aquatic vegetation (Lawrence 1975, Harrold \& Pearse 1987, Dayton et al. 1992, Shears \& Babcock 2002), and variation in their abun- 
dance and population structure can significantly alter the structure and function of benthic communities. In seagrass meadows, sea urchin densities can vary greatly, resulting in important consequences for herbivory rates (Prado 2007); sea urchin population outbursts can result in major overgrazing events and have been implicated in decline or local extinction of seagrasses (e.g. Camp et al. 1973, Heck \& Valentine 1995, Rose et al. 1999). The mechanisms governing such population outbursts in seagrass meadows are not clearly understood, although they appear to be the result of a combination of successful recruitment, refuge availability and release from predation pressure (Parker \& Shulman 1986, Rose et al. 1999, Prado 2007).

The seagrass meadows of the Mediterranean Sea are characterised by the high physical complexity of the dominant species, Posidonia oceanica (L.) Delile, which typically has dense leaf canopy (Heck \& Orth 1980) and robust rhizomes coated with the remains of old leaf sheaths. The net of interlacing rhizomes, roots and sediment form a dense root-rhizome layer (Romero et al. 1994) that can be either buried or partially exposed. When exposed, its crevices can provide potential refuges for prey species. Hence, in P. oceanica meadows, in addition to leaf canopy, gaps and burrows within the root-rhizome layer structure can be a potentially important factor in the survival of prey. However, the availability of these possible shelters often varies according to the biological features of the meadow and local environmental variables. Seagrass burial levels, for instance, can vary depending on the hydrodynamic regimes or sedimentation rates (Gacia et al. 1999), and the root-rhizome layer structure may be completely buried or exposed at different levels. In addition, shoot density and leaf length can be controlled by abiotic (e.g. hydrodynamic regimes, light conditions or water turbidity; Den Hartog 1970) or biotic conditions (e.g. herbivore activity; Heck \& Valentine 2006). In particular, herbivory pressure in the Mediterranean exhibits strong seasonal patterns, and can substantially modify seagrass leaf length (Tomas et al. 2005), thus altering refuge suitability of the seagrass canopy and opening the possibility of complex interactions between herbivores.

Posidonia oceanica meadows are commonly inhabited by the sea urchin Paracentrotus lividus (Lamarck), the most important invertebrate herbivore in the Mediterranean (Boudouresque \& Verlaque 2001). This sea urchin has been reported to consume up to an average of $17 \%$ of the annual leaf production, thus playing a central role in the trophic dynamics of the system; however, consumption withstands considerable spatial variation (from ca. 6 to $36 \%$ of the annual leaf production; Prado et al. 2007). Juvenile sea urchins seem to be present only in those meadows where the root-rhizome layer is unburied (Tomas et al. 2004, Prado 2007), which highlights the potential effect of this structure as a refuge for juveniles. In contrast, young adults are too large to hide within the root-rhizome layer (e.g. Tomas et al. 2005), yet not large enough to deter predators (Sala \& Zabala 1996). In the present study we investigated the relative refuge potential of different seagrass structural features for the sea urchin P. lividus against fish predation. We examined the role of the existence of the root-rhizome layer in order to confirm previous correlation results (Prado 2007), and the role of leaf length to explore possible indirect interactions among herbivores. We used a combination of field- and laboratory-based manipulative experiments, manipulating under controlled conditions these 2 features of seagrass habitat.

\section{MATERIALS AND METHODS}

The role of structural elements of Posidonia oceanica meadows (i.e. leaf canopy and root-rhizome layer) as refuges against predation for sea urchins was evaluated in different experiments, according to the size of the organisms involved. For small sea urchins (juveniles, 0.2 to $1.2 \mathrm{~cm}$ test diameter, TD) we tested the effects of leaf canopy and the presence of the rootrhizome layer on survival. For young adults ( 3 to $5 \mathrm{~cm}$ TD), we only investigated the effects of leaf canopy, as the crevices in the root-rhizome layer are too small to allow young adult sea urchins to enter (Tomas et al. 2004). Predation experiments were conducted both in the field and the laboratory. For young adults, experiments were performed in a Marine Protected Area (Medes Islands Marine Reserve, $42^{\circ} 16^{\prime} \mathrm{N}, 03^{\circ} 13^{\prime} \mathrm{E}$ ) where large predators (consumers of adult sea urchins) are abundant (Hereu et al. 2005). Juvenile sea urchins were too small to be successfully manipulated under field conditions, and predation experiments on these individuals were conducted in an aquarium, with a high density of potential predators.

Predation on juveniles. Two experiments were conducted with juvenile sea urchins within the aquaria facilities of the Aquàrium de Barcelona. Sea urchins, seagrass and sand were collected in February 2005 between 5 and $7 \mathrm{~m}$ depth off Blanes (NE Spain) using SCUBA and immediately transported to the Aquàrium for further sorting. Experimental units consisted of open transparent plastic boxes $(25 \mathrm{~cm}$ wide $\times 30 \mathrm{~cm}$ long $\times 16 \mathrm{~cm}$ high) with thin net walls $(2 \times 2 \mathrm{~mm}$ mesh size) in which different seagrass structures were constructed (see below and Fig. 1). A preliminary experiment revealed that juveniles were not able to escape from such experimental units. 
A number of seagrass shoots, including their respective rhizome and roots, similar to the natural density of local shallow meadows (i.e. 400 to 500 shoot $\mathrm{m}^{-2}$ ) and bearing, on average, $5.9 \pm 0.7$ leaves shoot ${ }^{-1}$ (Alcoverro et al. 1995) were placed in each of the boxes and anchored with cable ties. If necessary, sand was added to completely cover the rhizomes in order to eliminate crevices or other potential refuges. In the first experiment, we evaluated the role of seagrass canopy in decreasing fish predatory efficiency. To simulate different canopy conditions, leaves were cut as appropriate, and 3 treatments, each with 3 replicate units (boxes), were assembled: absence of leaves $(0 \mathrm{~cm})$, short leaves (all leaves longer than $7 \mathrm{~cm}$ were cut to $7 \mathrm{~cm}$ length) and long leaves (all leaves longer than $20 \mathrm{~cm}$ were cut to $20 \mathrm{~cm}$ length). In all 3 treatments, the rhizome layer was completely covered with sand (Fig. 1a). In the second experiment, we combined 2 treatments of leaf canopy (long leaves vs. short leaves) with 2 treatments of root-rhizome layer (presence vs. absence) in which rhizome crevices were available or filled with sand respectively (Fig. 1b). For each combination of treatments 3 replicates (independent experimental units, i.e. boxes) were used.

All boxes were placed in the bottom of a large tank (3500 l, 2 m diameter) with continuous seawater flow and containing the main guild of fish species known to prey on juvenile sea urchins (Boudouresque \& Verlaque 2001). Specifically, the tank contained a total of 31 Coris julis (L.), Labridae; 7 Diplodus sargus (L.) and 7 D. vulgaris (Geofr.), Sparidae, which were starved for $1 \mathrm{wk}$ prior to the start of the experiment. In addition, to reduce potential behavioural artefacts, boxes with no urchins were left inside the tank to allow acclimation of fish. After $4 \mathrm{~d}$, sea urchins $(\mathrm{n}=15)$ were added to each box and the experiment started. Three empty plastic

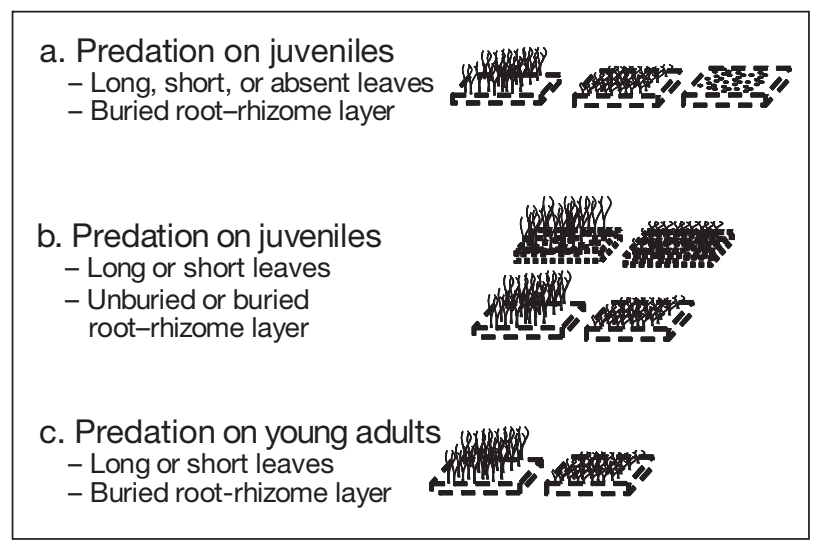

Fig. 1. Setup of predation experiments for juvenile and young adult sea urchins in different refuge conditions. Substrate type: buried (dashed) or unburied (dotted) root-rhizome layer. Leaf canopy length: long $(20 \mathrm{~cm})$, short $(7 \mathrm{~cm})$ or absent. control boxes with sea urchins $(\mathrm{n}=15)$ adhered to the bottom (using 2-component Ivergor putty) were also placed in the tank. These boxes allowed for the monitoring of predation when urchins were readily available to predators; these controls were used to determine the end-point of the experiments. After $15 \mathrm{~h}$, ca. $90 \%$ of individuals had been consumed in the controls, and experimental boxes were closed with a fine plastic mesh cover and removed from the tank; the number of remaining individuals in each treatment was then counted.

Predation on young adults. The protective effect of seagrass canopy against fish predation for young adults was evaluated in a shallow Posidonia oceanica meadow (ca. $5 \mathrm{~m}$ depth) at the Medes Islands Marine Reserve, where predators are very abundant and large enough to prey on young adults (Garcia-Rubies \& Zabala 1990). In addition, the experiment was conducted in summer (August 2005), when predators are more active (Sala \& Zabala 1996) and predatory potential is highest. We compared predation rates between plots (in natural stands) with short leaves (cut to $7 \mathrm{~cm}$ ) and plots with long leaves (cut to $20 \mathrm{~cm}$ ), and we also built control plots where urchins were totally exposed; the latter determined the end-point of the experiments (Fig. 1c).

Plots were $180 \times 180 \mathrm{~cm}$ in size, and 3 replicated plots were used for each treatment and control. Seagrass treatments (i.e. short leaves and long leaves) were marked with metal stakes and always carried out in areas where rhizomes were covered by sand. Control plots were set on unvegetated patches within the meadow, in which we placed a plastic mesh $(2 \mathrm{~cm}$ pore size, attached to the sand with stakes) to facilitate tethering of urchins.

Sea urchins ( 3 to $5 \mathrm{~cm}$ TD) were collected from rocky substrates near the study site using SCUBA. For each experimental plot, 12 ind. were pierced through the test with a hypodermic needle, threaded with monofilament line (50 cm length) and tied to a metal stakes (Aronson \& Heck 1995). Each tethered urchin was uniquely identified with a number and placed randomly inside the plot. The experiment concluded when more than $50 \%$ of individuals in the control plots had been consumed. This occurred within a $4 \mathrm{~d}$ period, after which stakes were removed and the remaining sea urchins counted.

Data analyses. We used ANOVA to assess the significance of differences among treatments, using sea urchin mortality (as a percentage relative to the initial number) in each box as the dependent variable. For the aquarium experiments, the effects of leaf length on predation pressure were tested with a 1-way ANOVA with leaf length as a fixed factor (3 levels: no leaves, short leaves and long leaves). Subsequently, the con- 
current influence of leaf canopy and availability of unburied root-rhizome layer structure on predation pressure was assessed using a 2-way ANOVA (with leaf length and root-rhizome layer structure as fixed factors, with 2 levels each).

For the field experiment, the effect of the seagrass canopy on predation pressure was assessed using a 1-way ANOVA with leaf length as a fixed factor (2 levels: short leaves and long leaves)

For all analyses, data were first tested for normality (Kolmogorov-Smirnov test) and homogeneity of variance (Cochran's test). When overall significant differences were detected, a posteriori pairwise comparisons of means were performed using a StudentNewman-Keuls (SNK) test (Zar 1989).

\section{RESULTS}

In the absence of exposed root-rhizome layer (first experiment), we detected that predation activity on juveniles was highly influenced by the presence of leaves. Mortality of juveniles was significantly lower when leaves were long $(29.1 \pm 11.0 \%$ mortality, mean $\pm \mathrm{SE})$ than when they were either short $(68.0 \pm 6.6 \%$ mortality) or absent $(56.7 \pm 5.1 \%$ mortality; SNK, $F=$ 6.327, $\mathrm{p}=0.033$ ) (Fig. 2).

When the effects of leaf canopy and root-rhizome layer were tested simultaneously (second experiment), both variables showed a strong influence on the predation of juveniles. Predation was lowest (mortality reaching values as low as $11 \pm 4.4 \%$ ) when the unburied root-rhizome layer was present, independent of leaf length (Table 1, Fig. 3). When the root-rhizome layer was buried, the treatment with long leaves showed less predation than that with short leaves (i.e.

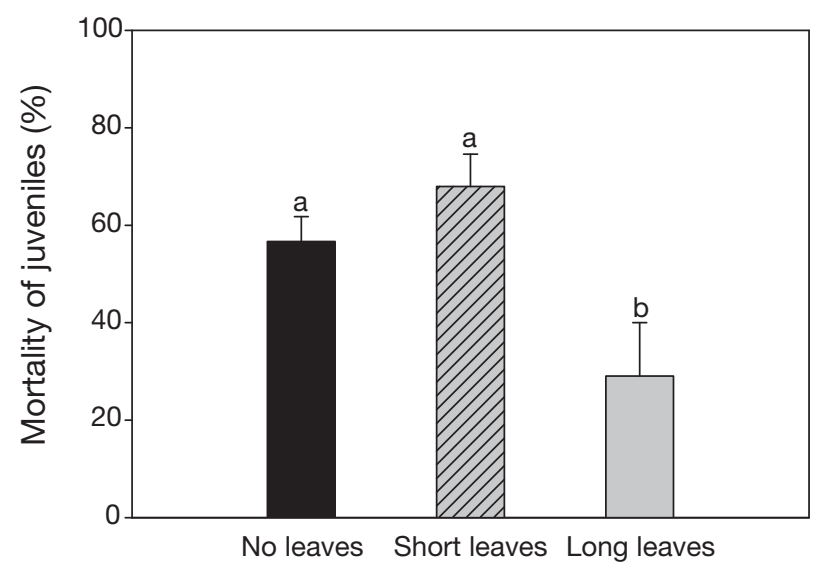

Fig. 2. Paracentrotus lividus. Percent mean ( \pm SE) mortality of juvenile sea urchins $(0.2$ to $1.2 \mathrm{~cm}$ test diameter, TD) under different canopy conditions. Different letters indicate significant differences between treatments (SNK)
Table 1. Two-way factorial ANOVA used to assess differences in predation pressure (\% mortality) on juvenile sea urchins by fish between substrate (root-rhizome layer: buried in sand vs. unburied) and canopy conditions (leaf length: short vs. long) and their interaction

\begin{tabular}{|lccrc|}
\hline Source & df & MS & \multicolumn{1}{c|}{$F$} & $\mathrm{p}$ \\
\hline Substrate (S) & 1 & 0.2896 & 25.5850 & 0.0009 \\
Leaf length (L) & 1 & 0.0778 & 6.8950 & 0.0304 \\
S $\times$ L & 1 & 0.0792 & 7.0090 & 0.0293 \\
Error & 8 & 0.1132 & & \\
\hline
\end{tabular}

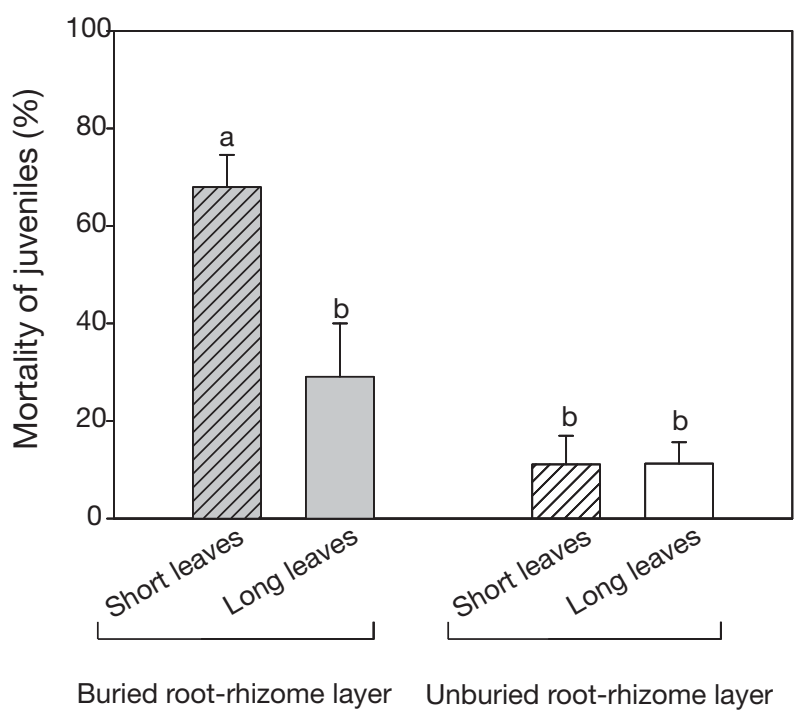

Fig. 3. Paracentrotus lividus. Percent mean ( \pm SE) mortality of juvenile sea urchins ( 0.2 to $1.2 \mathrm{~cm}$ TD) under different refuge conditions (i.e. rhizome habitat and canopy length). Different letters indicate significant differences between treatments (SNK)

significant leaf length $\times$ root-rhizome layer interaction) (Table 1). Similarly, in the field experiment we observed that mortality of young adults was significantly lower in plots with long leaves $(27.8 \pm 5.6 \%$ mortality) than in the treatment with short leaves $(80.6 \pm 12.1 \%$ mortality; ANOVA, $F=22.26455, \mathrm{p}=$ 0.009) (Fig. 4).

\section{DISCUSSION}

The present study provides strong support for the importance of refuges in alleviating predation pressure on sea urchins in seagrass meadows. Rates of predation on juvenile and young adult sea urchins were strongly influenced by variations in leaf canopy and the presence of bare rhizomes. Although we only manipulated leaf length to modify canopy structure, it is plausible that other structural features, such as shoot density, also influence the capacity of leaf canopy to 


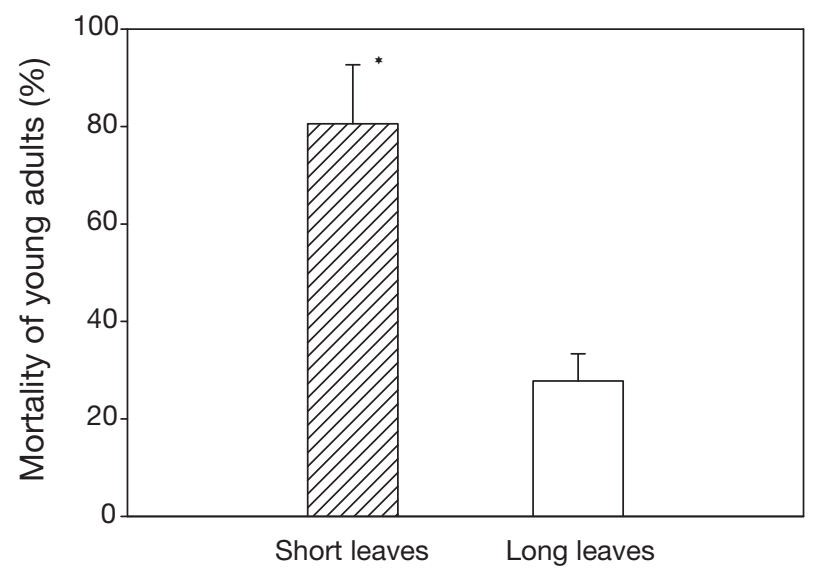

Fig. 4. Paracentrotus lividus. Percent mean ( \pm SE) mortality of young adult sea urchins ( 3 to $5 \mathrm{~cm}$ TD) under different canopy conditions. ${ }^{*}$ : significant differences

provide refuge against predation, particularly when rhizomes are buried. In fact, other authors have observed the existence of a threshold level in vegetation density which reduces predation intensity in other organisms inhabiting seagrass meadows (see Heck \& Orth 2006).

In the present study, the unburied root-rhizome layer appeared to be a key refuge for juvenile sea urchins, as its presence drastically reduced mortality, independently of leaf length. However, when this structure was unavailable to juveniles (i.e. buried by sand), dense seagrass canopy still provided some degree of protection. In contrast, dense seagrass canopy was the only effective refuge for young adults. These individuals are too large to hide within the root-rhizome layer (e.g. Tomas et al. 2005), yet not large enough to deter or resist predators (Sala \& Zabala 1996). Indeed, survival of young adults was significantly lower when leaf canopy was reduced or absent.

As these seagrass features are highly variable in space and time, the susceptibility of sea urchins to predation in seagrass meadows will depend not only on the abundance and size of predators and sea urchins, but also on the temporal availability of refuge sites. Burial of the root-rhizome layer depends on the sedimentary budget, which, in turn, is driven by local conditions (Gacia et al. 1999). For instance, a recent extensive survey of shallow seagrass meadows along $500 \mathrm{~km}$ of coastline in the NW Mediterranean reported that only 4 seagrass meadows, out of 10 sampled, showed a conspicuous presence of an exposed root-rhizome layer (Prado 2007). Leaf canopy structure, determined by leaf length and shoot density, is still more variable, as a result of light and nutrient availability (Alcoverro et al. 1997), grazing activity (see Heck \& Valentine 2006) and environmental conditions such as hydro- dynamic regimes and water turbidity (Longstaff \& Dennison 1999). Posidonia oceanica canopies can, for example, be strongly reduced by the grazing activity of herbivorous fish (Tomas et al. 2005, Prado et al. 2007) and, consequently, this can stimulate predation on young sea urchins. However, to adequately understand the effects of predation on sea urchins it should be recognised that predators of juveniles are different from those of young adults and adults. In effect, predation on juveniles is exerted by small fishes such as Coris julis and other small labrids (Hereu et al. 2005), while for young adults the most frequent predators are large sparids; while the latter are strongly affected by overfishing, the former are not (García-Rubies 1996, Sala 1997). Therefore, predation on juvenile sea urchins is likely of general occurrence and the abundance of juveniles may be dependent on the presence of the unburied root-rhizome layer. This contention is supported by Prado (2007), who reported that juveniles were only detected in meadows where a prominent root-rhizome layer was present.

In contrast, due to the loss of large predators as a result of fishing (Sala \& Zabala 1996), predation pressure on young adult and adult sea urchins is probably low in most seagrass meadows. However, the abundance of large fish predators is higher inside marine reserves than elsewhere (e.g. Sala \& Zabala 1996), and this can impact urchin populations. Again, this contention finds support in a large-scale survey of this region, which found lower densities of young adults as well as lower seagrass consumption rates by sea urchins inside marine reserves than elsewhere (Prado 2007).

In marine reserves, predation is enhanced both directly, by the increased abundance of predators, and indirectly, by the lower availability of dense canopies: the density of the herbivorous fish Sarpa salpa (L.) increases in marine protected areas (García-Rubies \& Zabala 1990), to the point that it has the capacity to strongly affect Posidonia oceanica canopies of shallow meadows, significantly reducing leaf length (Tomas et al. 2005). As our results indicate, this reduction in shoot length could significantly increase predation pressure on young adult sea urchins. This could be critically important during the summer months, when grazing activity by fish increases dramatically (Tomas et al. 2005) and predatory fish exert the highest predation pressure on sea urchins (Sala \& Zabala 1996). Although this hypothesis needs further experimental evidence, the existence of an indirect interaction between herbivorous fishes and the survival of young adult sea urchins seems consistent with the findings reported here and evidenced from the literature.

It has been well established for rocky bottom communities that the availability of refuges interacting 
with the size and behaviour of both predator and prey is crucial to the regulation of sea urchin populations and, consequently, in determining the state of algal communities (Witman \& Dayton 2001, Hereu 2004, Guidetti 2006, and references therein). In contrast, predator-prey interactions and their potential consequences are less studied in seagrass ecosystems and, within this context, the data presented here constitute a first step towards understanding this potentially important interaction. The present study has shown that the biotic (i.e. herbivory) and abiotic (i.e. sedimentation and hydrodynamic regime) processes that influence meadow architecture or structure have the potential to significantly affect predators' ability to control sea urchin population density. Any mechanism affecting a strongly interactive consumer (i.e. those potentially capable of causing community-wide effects) may have repercussions for the entire trophic dynamic of seagrass ecosystems. Through predation processes, herbivores are directly controlled by carnivores which, therefore, indirectly regulate plant abundance. This study highlights the existence of other factors and interactions that can indirectly alter this general topdown control. In this case, seagrass habitat structural complexity is a crucial element in regulating predation of a key herbivore in time and space by providing different refuges for different life stages.

Acknowledgements. We thank L'Aquàrium Barcelona for the use of aquaria facilities, and the Oficina de l'Àrea Protegida de les Illes Medes for allowing us to conduct experiments in the marine reserve. We also thank R. Arthur, S. Mariani, P. Carreras, and S. Escartín for field assistance. This work was supported by plan CGL2007-66771-C02-01 from the Spanish Ministry of Science and Education.

\section{LITERATURE CITED}

Alcoverro T, Duarte CM, Romero J (1995) Annual growth dynamics of Posidonia oceanica: contribution of largescale versus local factors to seasonality. Mar Ecol Prog Ser 120:203-210

Alcoverro T, Romero J, Duarte CM, Lopez NI (1997) Spatial and temporal variations in nutrient limitation of seagrass Posidonia oceanica growth in the NW Mediterranean. Mar Ecol Prog Ser 146:155-161

Aronson RB, Heck KL (1995) Tethering experiments and hypothesis testing in ecology. Mar Ecol Prog Ser 121: 307-309

Boudouresque CF, Verlaque M (2001) Ecology of Paracentrotus lividus. In: Lawrence JM (ed) Edible sea urchins: biology and ecology. Elsevier, Amsterdam, p 177-216

> Camp DK, Cobb SP, Van Breedveld JF (1973) Overgrazing of seagrasses by a regular urchin, Lytochinus variegatus. Bioscience 23:37-38

Dayton PK, Tegner MJ, Parnell PE, Edwards PB (1992) Temporal and spatial patterns of disturbance and recovery in a kelp forest community. Ecol Monogr 62:421-445

Den Hartog C (1970) The seagrasses of the world. Verhandelingen der Koninklijke Nederlandse Akademie van
Wetenschappen, afd, Natuurkunde, Tweede Reeks, no. 59, Amsterdam

Gacia E, Granata TC, Duarte CM (1999) An approach to measurement of particle flux and sediment retention within seagrass (Posidonia oceanica) meadows. Aquat Bot 65: $255-268$

García-Rubies A (1996) Estudi ecològic de les poblacions de peixos litorals sobre substrat rocós a la Mediterrània Occidental: efecte de la fondària, el substrat, l'estacionalitat i la protecció. PhD thesis, Universitat de Barcelona

García-Rubies A, Zabala M (1990) Effects of total fishing prohibition on the rocky fish assemblages of Medes Islands marine reserve (NW Mediterranean). Sci Mar 54:317-328

Guidetti P (2006) Marine reserves re-establish lost predatory interactions and cause community changes in rocky reefs. Ecol Appl 16:963-976

Harris LA, Buckley B, Nixon SW, Allen BT (2004) Experimental studies of predation by bluefish Pomatomus saltatrix in varying densities of seagrass and macroalgae. Mar Ecol Prog Ser 281:233-239

Harrold C, Pearse JS (1987) The ecological role of echinoderms in kelp forest. In: Jangoux M, Lawrence JM (eds) Echinoderm studies. A A Balkema, Rotterdam, p 137-233

Heck KL, Orth RJ (1980) Seagrass habitat: the roles of habitat complexity, competition and predation in structuring associated fish and motile macroinvertebrate assemblages. In: Kennedy VS (ed) Estuarine perspectives. Academic Press, New York, p 449-464

Heck KL, Orth RJ (2006) Predation in seagrass beds. In: Larkum AWD, Orth RJ, Duarte CM (eds) Seagrasses: biology, ecology and conservation. Springer, New York, p $537-550$

Heck KL, Valentine JF (1995) Sea urchin herbivory: evidence for long-lasting effects in subtropical seagrass meadows. J Exp Mar Biol Ecol 189:205-217

> Heck KL, Valentine JF (2006) Plant-herbivore interactions in seagrass meadows. J Exp Mar Biol Ecol 330:420-436

Heck KL, Wilson K (1986) Predation rates on decapod crustaceans in latitudinally separated seagrass communities: a study of spatial and temporal variation using tethering techniques. Ecology 107:87-100

Heck KL, Able KW, Fahay MP, Roman CT (1989) Fishes and decapod crustaceans of Cape Cod eelgrass meadows: species composition, seasonal abundance patterns and comparison with unvegetated substrates. Estuaries 12:59-65

Hereu B (2004) The role of trophic interactions between fishes, sea urchins and algae in the north-western Mediterranean rocky infralittoral. PhD thesis, University of Barcelona

Hereu B, Zabala M, Linares C, Sala E (2005) The effects of predator abundance and habitat structural complexity on survival of juvenile sea urchins. Mar Biol 146:293-299

Lawrence JM (1975) The relationships between echinoids and marine plants. Oceanogr Mar Biol Annu Rev 13: 213-286

> Longstaff BJ, Dennison WC (1999) Seagrass survival during pulsed turbidity events: the effect of light deprivation on the seagrasses Halodule pinifolia and Halophila ovalis. Aquat Bot 65:105-121

Orth RJ (1992) A perspective on plant-animal interactions in seagrasses: physical and biological determinants influencing plant and animal abundance. In: John DM, Hawkins SJ, Price JH (eds) Plant-animal interactions in the marine benthos. Syst Assoc 46:147-164

Orth RJ, Heck KL Jr, Van Montfrans J (1984) Faunal communities in seagrass beds: a review of the influence of plant structure and prey. Estuaries 7:339-350 
Parker DA, Shulman MJ (1986) Avoiding predation: alarm responses of Caribbean sea urchins to simulated predation on conspecific and heterospecific sea urchins. Mar Biol 93: 201-208

Prado P (2007) Magnitude of herbivory in Posidonia oceanica and factors responsible for spatial variation. PhD thesis, University of Barcelona

Prado P, Tomas F, Alcoverro T, Romero J (2007) Extensive direct measurements of Posidonia oceanica defoliation confirm the importance of herbivory in temperate seagrass meadows. Mar Ecol Prog Ser 340:63-71

Romero J, Pérez M, Mateo MA, Sala E (1994) The belowground organs of the Mediterranean seagrass Posidonia oceanica as a biogeochemical sink. Aquat Bot 47:13-19

Rose CD, Sharp WC, Kenworthy WJ, Hunt JH and others (1999) Overgrazing of a large seagrass bed by the sea urchin Lytechinus variegatus in Outer Florida Bay. Mar Ecol Prog Ser 190:211-222

Sala E (1997) Fish predators and scavengers of the sea urchin Paracentrotus lividus in protected areas of the north-west Mediterranean Sea. Ecology 129:531-539

Sala E, Zabala M (1996) Fish predation and the structure of

Editorial responsibility: John Lawrence,

Tampa, Florida, USA the sea urchin Paracentrotus lividus populations in the NW Mediterranean. Mar Ecol Prog Ser 140:71-81

Savino F, Stein RA (1982) Predator-prey interaction between largemouth bass and bluegills as influenced by simulated, submersed vegetation. Trans Am Fish Soc 111:255-266

Shears NT, Babcock RC (2002) Marine reserves demonstrate top-down control of community structure on temperate reefs. Oecologia 132:131-142

Tomas F, Romero J, Turon X (2004) Settlement and recruitment of the sea urchin Paracentrotus lividus in two contrasting habitats in the Mediterranean. Ecology 282: 173-184

Tomas F, Turon X, Romero J (2005) Seasonal and small-scale spatial variability of herbivory pressure on the temperate seagrass Posidonia oceanica. Mar Ecol Prog Ser 301: 95-107

Witman JD, Dayton PK (2001) Rocky subtidal communities. In: Bertness MD, Gaines SD, Hay ME (eds) Marine community ecology. Sinauer Associates, Sunderland, MA, p 339-366

Zar JH (1989) Biostatistical analysis, 2nd edn. Prentice Hall, Englewood Cliffs, NJ

Submitted: March 4, 2008; Accepted: August 12, 2008

Proofs received from author(s): January 29, 2009 